\title{
Effect of Sodium Chloride Concentration on Saturated Permeability of Remolded Loess
}

\author{
Panpan Xu ${ }^{1,2}$, Qiying Zhang ${ }^{1,2}$, Hui Qian ${ }^{1,2, * \mathbb{C}}$ and Wengang Qu ${ }^{1,2}$ \\ 1 School of Water and Environment, Chang'an University, Xi'an 710054, China; xupanpan0212@163.com (P.X.); \\ zhangqiying@chd.edu.cn (Q.Z.); 2019029003@chd.edu.cn (W.Q.) \\ 2 Key Laboratory of Subsurface Hydrology and Ecological Effects in Arid Region of the Ministry of Education, \\ Chang'an University, Xi'an 710054, China \\ * Correspondence: qianhui@chd.edu.cn
}

Received: 22 January 2020; Accepted: 20 February 2020; Published: 22 February 2020

\begin{abstract}
Loess contains many sodium and chloride ions that can easily be leached when seepage occurs, thus affecting the mechanical properties of loess. This study investigated a series of sodium chloride solution concentrations to explore their influence on the permeability of remolded loess, as well as the underlying mechanism of such. The results indicated that the saturated hydraulic conductivity of remolded loess increases with time in response to different sodium chloride concentrations, and the sample was more permeable with increasing concentration. Moreover, the salt effect promoted the dissolution of calcite and dolomite, and the cation exchange stimulated the leaching of other cations, thus leading to further structural loosening. Furthermore, the aggregation of clay particles increased, thus forming a larger pore space among aggregates and providing effective channels for permeation. These findings provide a theoretical basis for an improved understanding of channel degradation in the loess area of Northwest China.
\end{abstract}

Keywords: sodium chloride; saturated permeability; remolded loess; concentration

\section{Introduction}

Loess is widely distributed throughout the arid and semi-arid regions of the world, accounting for approximately $10 \%$ of the global land area [1,2]. Loess has become a popular foundation of various engineering constructions because of its characteristics of simple development and low cost. However, seepage is an important reason for the decline of loess's engineering properties [3]. In the loess area of Northwest China, a large number of structures, such as loess dams and loess canals, have changed the soil structure. The reasons for this are a series of soil and water interactions in the process of seepage that threaten the safe operation of these structures [4]. Therefore, it is of great significance to investigate the permeability behavior of remolded loess in response to soil and water interactions.

Seepage is directly linked to hydraulic conductivity, which is an important index that describes the ease with which water moves through soil $[5,6]$. At present, much experimental research has been conducted on the influence of water and soil interactions on the permeability of soil, both in China and internationally. Several scholars have found that hydration can be induced-to achieve a change of permeability - by adding materials, such as lime, cement, and fly ash, to the soil [7-11]. In addition, in-depth studies have been conducted that have shown that changes of hydraulic conductivity are related to the type and concentration of inorganic solutions [12-15]. The chemical composition during the leaching process has been studied to reverse the changing mechanism that underlies permeability [16-19]. During the process of seepage, water and soil interactions like dissolution and precipitation, exchange and adsorption, hydration and hydrolysis, as well as redox reactions, take place. 
These effects promote the transfer of components between soil and fluid, thus leading to changes of the surface morphology of particles and strengthening the soil structure [20-23].

Furthermore, the chemical compositions in a solution can change the electrochemical environment of soil and the content of clay particle-bound water [24]. A number of studies have deeply discussed the changes of the diffuse double layer on the surface of clay particles that are caused by the type and concentration of the solution. These studies have suggested that hydraulic conductivity is closely related to the thickness of the diffuse double layer $[19,21,25]$. Increasing salt concentration can enhance permeability by decreasing the thickness of the diffuse double layer, which also leads to the flocculation of clay particles and the change of their microstructure [14,24,26,27].

The cations in loess are dominated by $\mathrm{Na}^{+}$, while the anions are dominated by $\mathrm{Cl}^{-}$and $\mathrm{SO}_{4}{ }^{2-}$ [28]. These ions leach away with water, thus affecting both the structure and mechanical properties of loess in the process of seepage. Therefore, this study selected a sodium chloride solution to permeate remolded loess. The changes of the chemical composition in the permeate were measured, and the chemical components and microstructure of the soil samples after permeation were investigated by $X$-ray fluorescence (XRF) and scanning electron microscopy (SEM).

The first objective was to determine how the saturated permeability behavior of the remolded loess changed with the concentration of sodium chloride. The second objective was to identify the relationship between the content of chemical ions in the permeate and the saturated conductivity. The third objective was to explore the chemical interaction of the soil and the water in the process of seepage, as well as the evolution of the soil microstructure after seepage. Furthermore, the response mechanism of the variation of the saturated permeability of remolded loess to different concentrations of an $\mathrm{NaCl}$ solution is summarized.

\section{Materials and Methods}

\subsection{Materials}

The $\mathrm{Q}_{3}$ loess (known as Malan loess in China) in Gaozhuang Town, Jingyang County, Shaanxi Province, China, was selected as the remolded soil material (Figure 1). After the loess material was transported to the laboratory, a series of physical properties were measured according to the standard for soil test methods of the P. R. China [29], as shown in Table 1. The maximum dry density and optimum moisture content were determined by a standard compaction test [30]. The specific gravity was measured by a pycnometer method. The liquid and plastic limits were tested by using a liquid-plastic combine tester. The grain size distribution was measured with a WJL-602 laser particle size analyzer. The studied loess was composed of $73.44 \%$ silt, $26.36 \%$ clay, and $0.20 \%$ sand based on the standard of particle partitioning [31]. Moreover, the chemical analysis of the loess that was used in this study was conducted by using the ZSX Primus II XRF spectrometer (Rigaku, Tokyo, Japan). Table 2 shows that $\mathrm{SiO}_{2}$ dominated the chemical composition of the loess, and this was followed by $\mathrm{Al}_{2} \mathrm{O}_{3}, \mathrm{CaO}$, and $\mathrm{Fe}_{2} \mathrm{O}_{3}$. A mineralogical analysis was conducted by $\mathrm{D} /$ max-2500 X-ray diffraction (XRD) (Rigaku, Tokyo, Japan). The results indicated that quartz dominated the mineral composition, and eight other minerals were identified: plagioclase, illite, calcite, chlorite, orthoclase, dolomite, amphibole, and hematite (Table 3). In addition, the loess samples were scanned by an FEI Quanta 200 SEM (Eindhoven, The Netherlands) to obtain their microstructure. 


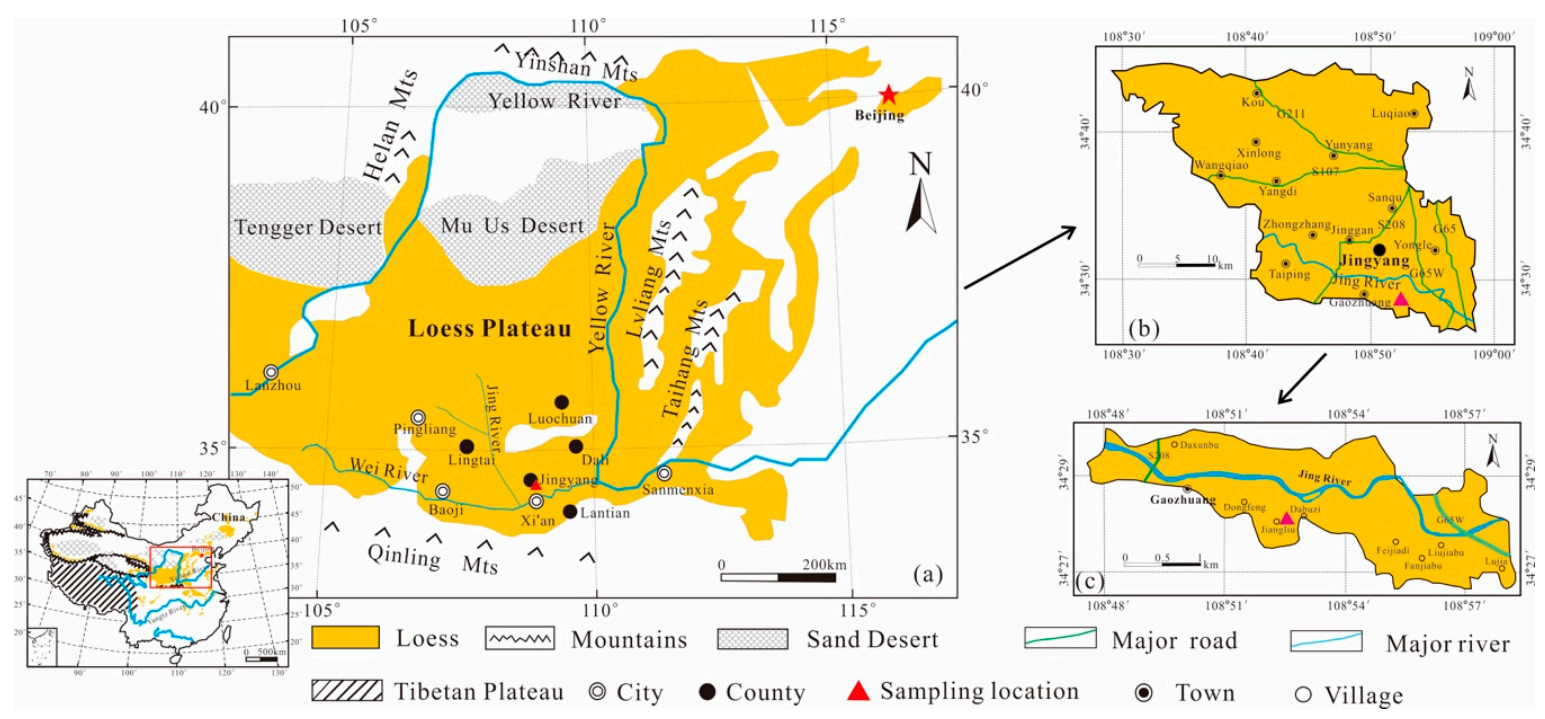

Figure 1. Location map of loess distribution and sampling position in China. (a) Distribution of the Chinese Loess Plateau in China, (b) map of Jingyang County, (c) map of Gaozhuang Town.

Table 1. Physical properties of the loess that was used in this study.

\begin{tabular}{|c|c|c|c|c|c|c|c|}
\hline \multirow{2}{*}{$\begin{array}{c}\text { Optimal } \\
\text { Moisture } \\
\text { Content/\% }\end{array}$} & \multirow{2}{*}{$\begin{array}{l}\text { Maximum Dry } \\
\text { Density } / \mathrm{g} \cdot \mathrm{cm}^{-3}\end{array}$} & \multirow{2}{*}{$\begin{array}{c}\text { Specific } \\
\text { Gravity } \\
G_{s}\end{array}$} & \multirow{2}{*}{$\begin{array}{l}\text { Liquid } \\
\text { Limit/\% }\end{array}$} & \multirow{2}{*}{$\begin{array}{l}\text { Plastic } \\
\text { Limit/\% }\end{array}$} & \multicolumn{3}{|c|}{ Grain Size Distribution/\% } \\
\hline & & & & & $\begin{array}{c}\text { Clay } \\
(<5 \mu \mathrm{m})\end{array}$ & $\begin{array}{c}\text { Silt } \\
(5-50 \mu \mathrm{m})\end{array}$ & $\begin{array}{c}\text { Sand } \\
(>50 \mu \mathrm{m})\end{array}$ \\
\hline 17.07 & 1.74 & 2.71 & 36.9 & 19.8 & 26.36 & 73.44 & 0.20 \\
\hline
\end{tabular}

Table 2. Major chemical composition of the loess that was used in the experiment.

\begin{tabular}{ccccccccc}
\hline Nominal Oxide & $\mathrm{SiO}_{2}$ & $\mathrm{Al}_{2} \mathbf{O}_{3}$ & $\mathbf{C a O}$ & $\mathbf{K}_{2} \mathbf{O}$ & $\mathrm{Na}_{2} \mathbf{O}$ & $\mathbf{M g O}$ & $\mathrm{Fe}_{2} \mathrm{O}_{3}$ & Others \\
\hline wt. $\%$ & 52.21 & 13.19 & 9.07 & 2.77 & 1.15 & 3.34 & 5.75 & 12.52 \\
\hline
\end{tabular}

Table 3. Mineralogical composition of the loess that was used in the experiment.

\begin{tabular}{cccccccccc}
\hline Mineral & Quartz & Plagioclase & Illite & Calcite & Chlorite & Orthoclase & Dolomite & Amphibole & Hematite \\
\hline wt. $\%$ & 43.1 & 13.5 & 11 & 10.9 & 7.9 & 7.5 & 4.4 & 1.5 & 0.2 \\
\hline
\end{tabular}

\subsection{Preparation of Specimens}

The preparation process of the remolded loess sample is shown in Figure 2. The collected loess was air-dried under natural conditions, then rolled and sieved to $2 \mathrm{~mm}$, and placed in an oven at $105^{\circ} \mathrm{C}$ until it was fully dry. To reduce the influence of different moisture contents on the experimental results, quantitative deionized water was sprayed on the dried loess according to the optimal moisture content $(\sim 17 \%)$, and then the loess was put into a fresh-keeping bag for 1 day after evenly mixing. Next, the water content of the fully mixed soil, which was obtained by inverse calculation, ensured that the deviation from the optimal moisture content was controlled within $\pm 0.2 \%$. Finally, the pre-treatment soil was compacted in a three-axis compactor to obtain remolded loess samples with a dry density of $1.45 \mathrm{~g} \cdot \mathrm{cm}^{-3}$ (diameter of $61.8 \mathrm{~mm}$ and height of $40 \mathrm{~mm}$ ), which were ready for permeation. 


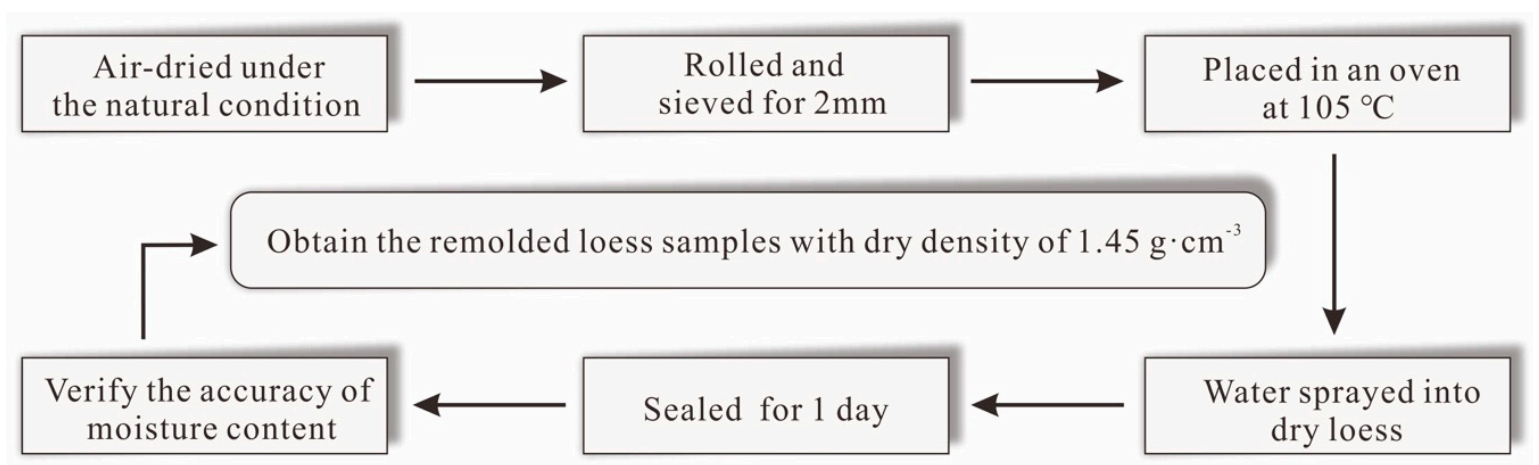

Figure 2. The process of the remolded loess specimen preparation.

\subsection{Solutions}

The concentration and composition of ions in pore water affects the properties of soil [32]. The cation and anion in loess are dominated by $\mathrm{Na}^{+}$and $\mathrm{Cl}^{-}$, respectively [28]. In this study, sodium chloride $(\mathrm{NaCl})$ was used to study the effect of soluble salt on the saturated permeability coefficient. $\mathrm{NaCl}$ was dissolved in deionized water to obtain a series of desired concentrations, including 0.001 , $0.0025,0.005,0.01$, and $0.1 \mathrm{~mol} / \mathrm{L}$. Deionized water was assumed as an $\mathrm{NaCl}$ solution of $0 \mathrm{~mol} / \mathrm{L}$.

\subsection{Saturated Hydraulic Conductivity Test}

\subsubsection{Test Apparatus}

The structure of the saturated hydraulic conductivity test apparatus basically consisted of a tank with a water source (volume of $15 \mathrm{~L})$, a constant-head tank $(10 \times 20 \times 26 \mathrm{~cm})$, three screw regulators, a catchment tank, a piezometer tube, and a TST-55 permeameter (Figure 3). The tank of the water source provided deionized water for the constant-head tank. By adjusting the constant-head tank, a dynamic balance of the whole seepage system was realized, and the stability of the water head was maintained. The value of the head was observed by using the piezometer tube. The saturated hydraulic conductivity $\left(K_{\text {sat }}\right)$ was tested by using the TST-55 permeameter (China).

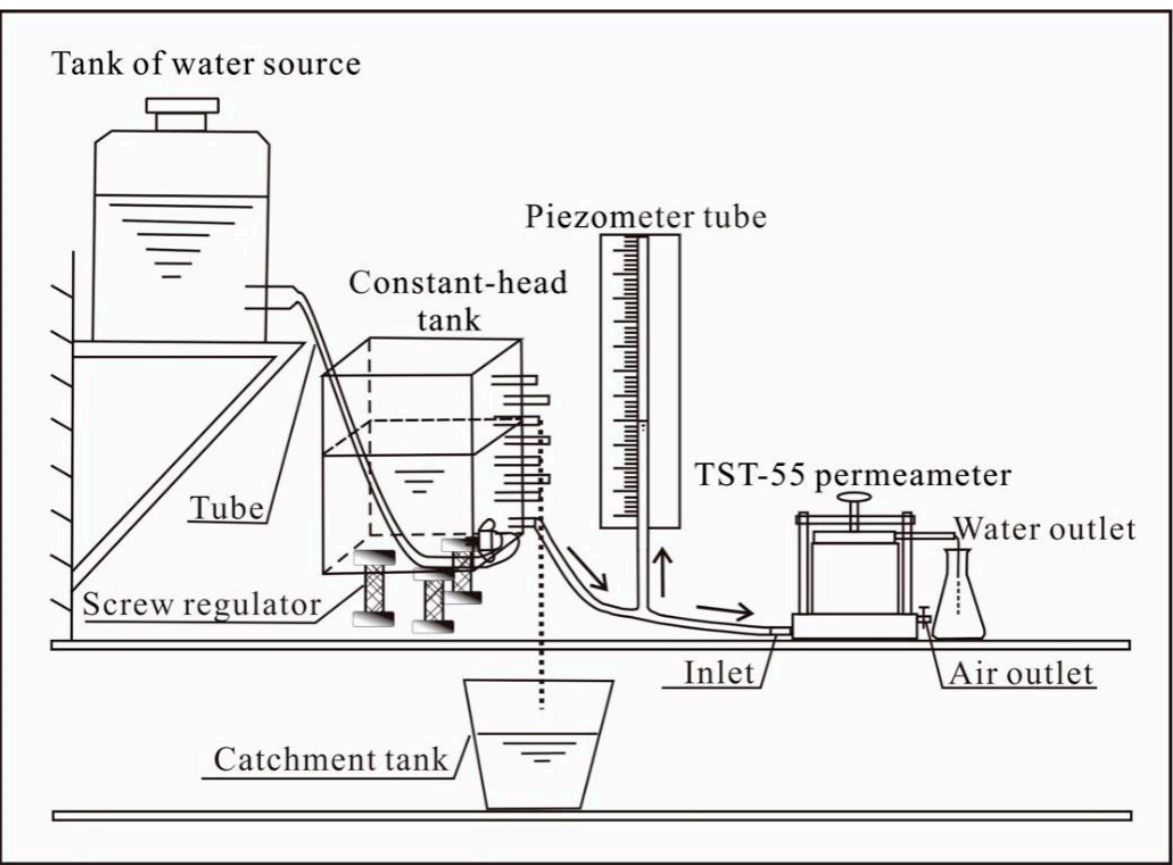

Figure 3. Saturated permeability test apparatus. 


\subsubsection{Sample Saturation}

The saturation process of the soil specimens was performed by using the constant head method. Firstly, the height of the solution in the constant-head tank (i.e., the value of the piezometer tube head) remained constant with the elevation at the bottom of the sample. Secondly, the solution slowly permeated the testing sample to keep the water level rising at a rate of $1 \mathrm{~cm} / 6 \mathrm{~h}$ to thoroughly remove air from the pores. The high water pressure that was produced by the fast flow rate led to bubble rupture and affected the permeability [33]. Finally, the water level reached the top of the sample, which was defined as sample saturation after the constant-head rose four times. In addition, water flowed from the bottom to the top of the TST- 55 permeameter to avoid any residual air from affecting the permeability of soil samples [10].

\subsection{3. $K_{\text {sat }}$ Measurement}

Laboratory hydraulic conductivity tests are typically applied to obtain saturated hydraulic conductivity $\left(K_{s a t}\right)$ and to describe the ease of water movement through fine and clayey porous media [5,7]. In this study, the $K_{\text {sat }}$ of the remolded loess samples was measured via the constant head test method after saturation. According to Darcy's law, the $K_{\text {sat }}$ can be calculated as follows:

$$
\begin{aligned}
K_{\text {sat }} & =\frac{Q}{A \cdot i \cdot t} \\
i & =\frac{\Delta H}{L}
\end{aligned}
$$

where $K_{\text {sat }}$ is the saturated hydraulic conductivity $(\mathrm{cm} / \mathrm{s}), Q$ is the quantity of water $\left(\mathrm{cm}^{3}\right), A$ is the cross-sectional area perpendicular to flow $\left(\mathrm{cm}^{2}\right), t$ is the time (s) required for $Q$ to be discharged, $i$ is hydraulic gradient, $\Delta h$ is the head difference between the top and the bottom of the soil specimen $(\mathrm{cm})$, and $L$ is length of the seepage path (i.e., the height of the sample) $(\mathrm{cm})$.

The influence of temperature on saturated permeability cannot be neglected [6,34-36]; therefore, the test apparatus was placed in an $\mathrm{SHH}-\mathrm{C} 3000$ constant temperature controller (China) with a range of $0-60{ }^{\circ} \mathrm{C}$ and an accuracy of $0.1{ }^{\circ} \mathrm{C}$. In this study, $20^{\circ} \mathrm{C}$ was set as the standard temperature to avoid the correction of $K_{s a t}$ [37]. Moreover, the hydraulic gradient was set to 3 to ensure sufficient discharge for the water chemical analysis.

\subsection{Water Chemical Analysis}

Leachate samples were taken every $12 \mathrm{~h}$ to analyze chemical characteristics, and the experimental period was 7 days. Once the volume of the leachate was recorded, the $\mathrm{pH}$, total dissolved solids (TDS), and bicarbonate were immediately obtained. The $\mathrm{pH}$ and TDS were tested by using a multifunctional water quality tester (model: AZ86505, Heng Xin, Taiwan, China), and bicarbonate was measured with a neutralization titration method. The leachate was filtered through a $0.45 \mu \mathrm{m}$ water phase filter and stored in two $10 \mathrm{~mL}$ centrifuge tubes. The concentrations of the anions $\left(\mathrm{F}^{-}, \mathrm{Cl}^{-}\right.$, and $\left.\mathrm{SO}_{4}{ }^{2-}\right)$ were measured with an ion chromatograph (DIONEX-ICS-600, Thermo Scientific, Sunnyvale, CA, USA) with an analytical accuracy below $5 \%$. For cation analysis, the water samples were acidified with pure nitric acid to $\mathrm{pH}<2$, and the concentrations of $\mathrm{Na}^{+}, \mathrm{K}^{+}, \mathrm{Ca}^{2+}$, and $\mathrm{Mg}^{2+}$ were measured with an ICAP6300 spectrometer (DIONEX, Sunnyvale, CA, USA) with a measurement accuracy below 5\%.

\section{Results}

\subsection{Variation Characteristics of $K_{\text {sat }}$}

The change characteristics of $K_{\text {sat }}$ with time were obtained by permeating six different concentrations of the sodium chloride solution in the remolded loess samples, as shown in Figure 4a. It can be seen that the $K_{\text {sat }}$ of the remolded loess samples with a dry density of $1.45 \mathrm{~g} \cdot \mathrm{cm}^{-3}$ increased 
with time during the entire process of permeation. Moreover, with the increasing $\mathrm{NaCl}$ concentration, the degree of $K_{\text {sat }}$ increase was higher. To quantify the increase in saturated permeability, the increment of saturated hydraulic conductivity $(\Delta K)$ was introduced by using the following equation:

$$
\Delta K=K_{f}-K_{i}
$$

where $\Delta K$ represents the increment of saturated hydraulic conductivity $\left(\mathrm{cm} \cdot \mathrm{s}^{-1}\right)$ and $K_{i}$ and $K_{f}$ represent the initial and final saturated hydraulic conductivity $\left(\mathrm{cm} \cdot \mathrm{s}^{-1}\right)$, respectively.

According to Table 4 , the increment of $K_{\text {sat }}$ of the samples $\left(C_{\mathrm{NaCl}}=0,0.001,0.0025,0.005,0.01\right.$, and $0.1 \mathrm{~mol} \cdot \mathrm{L}^{-1}$ ) were $1.11 \times 10^{-6}, 5.00 \times 10^{-6}, 5.68 \times 10^{-6}, 7.05 \times 10^{-6}, 8.44 \times 10^{-6}$, and $2.08 \times 10^{-5}$ $\mathrm{cm} \cdot \mathrm{s}^{-1}$, respectively. The results indicated that the hydraulic conductivity of the saturated remolded loess was sensitive to the concentrations of the $\mathrm{NaCl}$ solution. Furthermore, the average values of their corresponding $K_{\text {sat }}$ were $1.50 \times 10^{-5}, 1.80 \times 10^{-5}, 1.84 \times 10^{-5}, 1.90 \times 10^{-5}, 2.00 \times 10^{-5}$, and $2.30 \times 10^{-5}$ $\mathrm{cm} \cdot \mathrm{s}^{-1}$, respectively (Figure $4 \mathrm{~b}$ ). For $\mathrm{NaCl}$ concentrations of $0.001,0.0025,0.005,0.01$, and $0.1 \mathrm{~mol} \cdot \mathrm{L}^{-1}$, the mean values of $K_{\text {sat }}$ were up to $1.20,1.22,1.26,1.33$, and 1.53 times higher, respectively, than those for deionized water. This also suggested that the increases in the permeant $\mathrm{NaCl}$ concentration led to significant increases in $K_{\text {sat }}$.

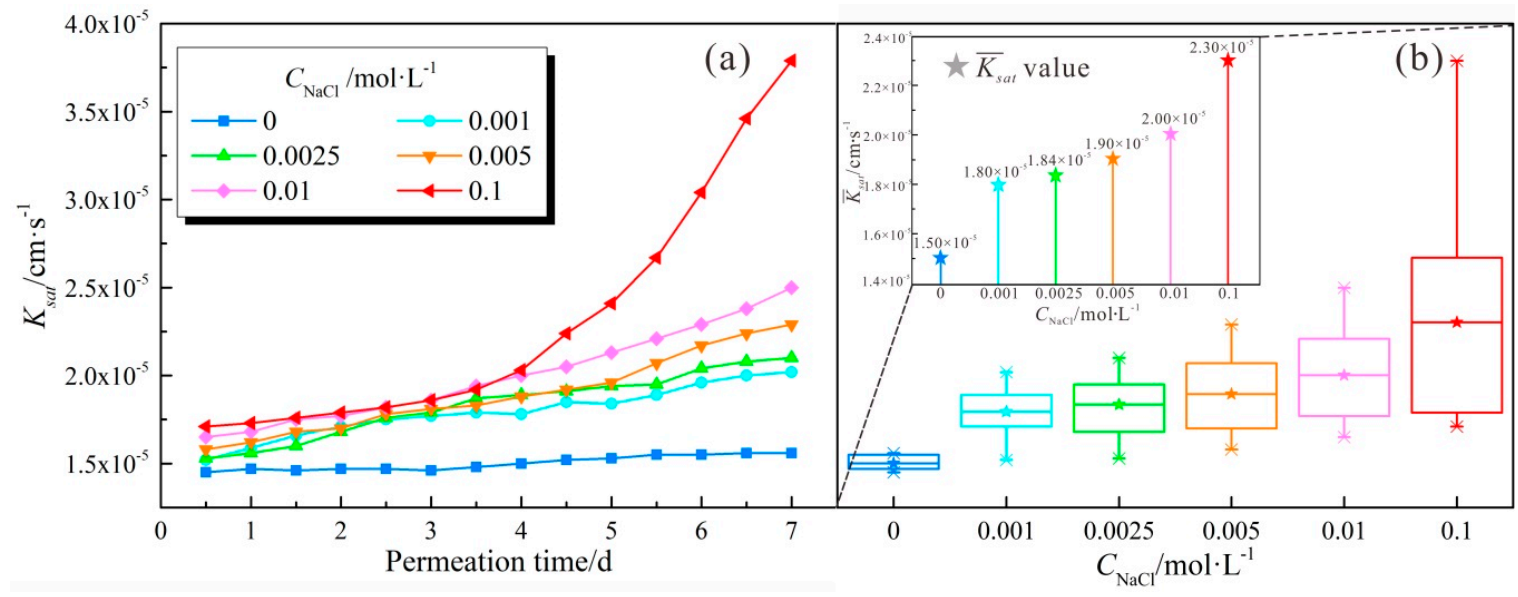

Figure 4. Variation characteristics of saturated hydraulic conductivity. (a) The change of saturated hydraulic conductivity $\left(K_{s a t}\right)$ with permeation time and (b) distribution range of the $K_{\text {sat }}$ value.

Table 4. Change in the saturated hydraulic conductivity of the samples.

\begin{tabular}{ccccccc}
\hline$C_{\mathbf{N a C l}}\left(\mathbf{m o l} \cdot \mathbf{L}^{-\mathbf{1}}\right)$ & $\mathbf{0}$ & $\mathbf{0 . 0 0 1}$ & $\mathbf{0 . 0 0 2 5}$ & $\mathbf{0 . 0 0 5}$ & $\mathbf{0 . 0 1}$ & $\mathbf{0 . 1}$ \\
\hline$K_{i}\left(\mathrm{~cm} \cdot \mathrm{s}^{-1}\right)$ & $1.45 \times 10^{-5}$ & $1.52 \times 10^{-5}$ & $1.53 \times 10^{-5}$ & $1.58 \times 10^{-5}$ & $1.65 \times 10^{-5}$ & $1.71 \times 10^{-5}$ \\
$K_{\mathrm{f}}\left(\mathrm{cm} \cdot \mathrm{s}^{-1}\right)$ & $1.56 \times 10^{-5}$ & $2.02 \times 10^{-5}$ & $2.10 \times 10^{-5}$ & $2.29 \times 10^{-5}$ & $2.50 \times 10^{-5}$ & $3.79 \times 10^{-5}$ \\
$\Delta K\left(\mathrm{~cm} \cdot \mathrm{s}^{-1}\right)$ & $1.11 \times 10^{-6}$ & $5.00 \times 10^{-6}$ & $5.68 \times 10^{-6}$ & $7.05 \times 10^{-6}$ & $8.44 \times 10^{-6}$ & $2.08 \times 10^{-6}$ \\
\hline
\end{tabular}

\subsection{Chemical Characteristics of the Leachate}

The effects of the $\mathrm{NaCl}$ solution on the chemical components of the permeate over time are shown in Figure 5. The values of $\mathrm{K}^{+}, \mathrm{Mg}^{2+}, \mathrm{Ca}^{2+}, \mathrm{SO}_{4}{ }^{2-}$, and $\mathrm{HCO}_{3}{ }^{-}$decreased with permeation time, while the $\mathrm{F}^{-}$values first increased and then decreased. For the sodium chloride with concentrations between 0 and $0.01 \mathrm{~mol} \cdot \mathrm{L}^{-1}$, the $\mathrm{Na}^{+}$and $\mathrm{Cl}^{-}$values gradually decreased over time and were close to their concentrations in the influent solution. However, $\mathrm{Na}^{+}$gradually increased until it was close to the concentrations of $\mathrm{Na}^{+}$in the $0.1 \mathrm{~mol} \cdot \mathrm{L}^{-1} \mathrm{NaCl}$ solution, and the changing trend of $\mathrm{Cl}^{-}$was not obvious. 

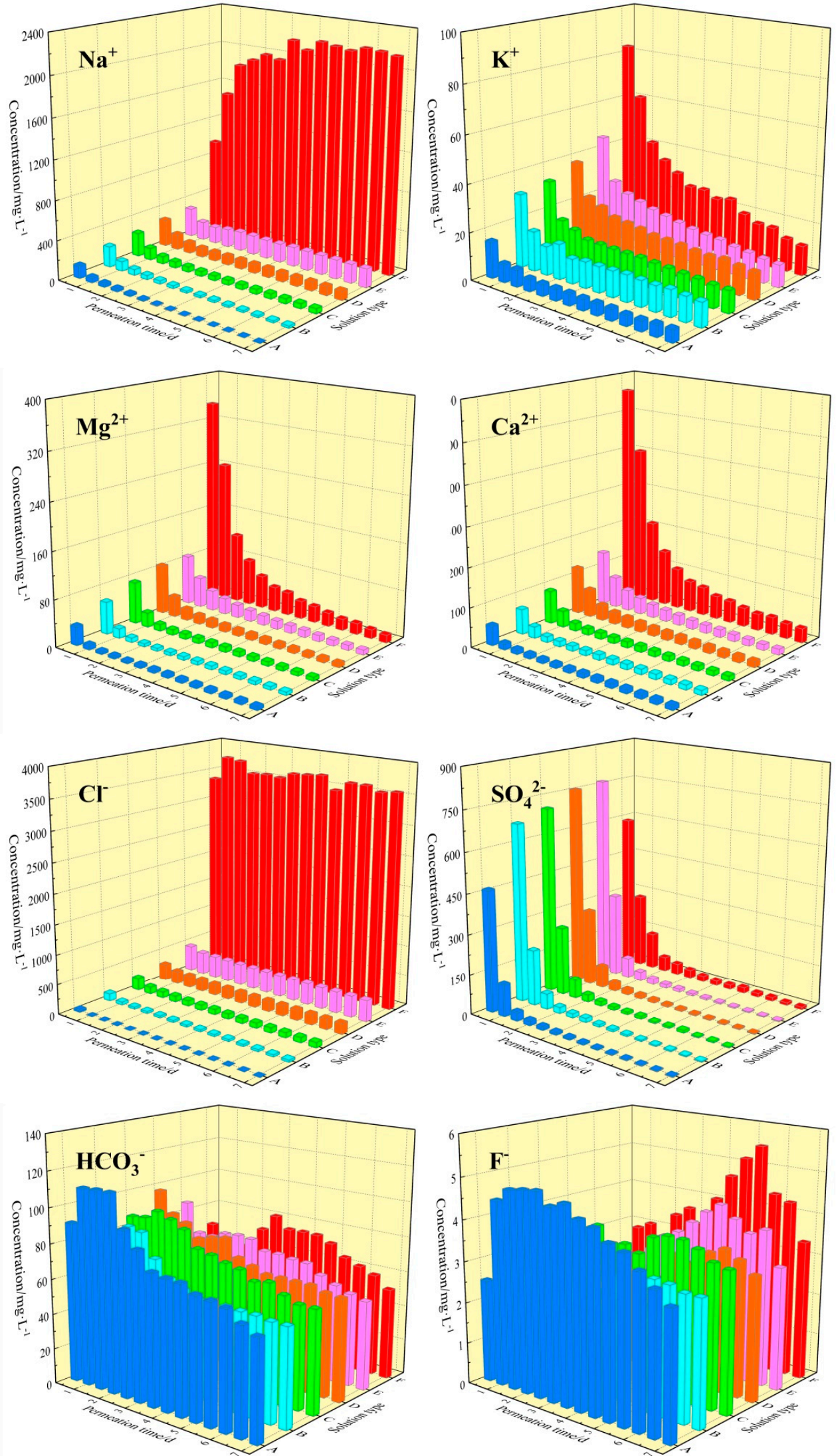

Figure 5. Change characteristics of the chemical components of the leachate with time. Solution types of A, B, C, D, E, and F represent $0,0.001,0.0025,0.005,0.01$, and $0.1 \mathrm{~mol} / \mathrm{L}$, respectively. 


\subsection{Desalination Effect of Soil}

The effect of the $\mathrm{NaCl}$ concentration on soil desalination was evaluated by statistical analysis of the water chemical compositions of the leachate, and the total cumulative mass $\left(M_{T}\right)$ was defined as [18]:

$$
M_{T}=\sum_{i=1}^{14}\left(V_{i} \times m_{i}\right)
$$

where data were recorded every $12 \mathrm{~h}$; therefore, a total of 14 samples were taken during the experimental period, $M_{T}$ represents the total cumulative mass of ions in the permeate $(\mathrm{mg}), V_{i}$ represents the volume of the permeate that was recorded each time $(\mathrm{L})$, and $m_{i}$ represents the mass concentration of the ions $\left(\mathrm{mg} \cdot \mathrm{L}^{-1}\right)$.

Figure 6 shows the effect of the different concentrations of sodium chloride on salt removal in the remolded loess samples. The effect on $\mathrm{Ca}^{2+}$ was most significant, followed by that on $\mathrm{Mg}^{2+}, \mathrm{SO}_{4}{ }^{2-}$, and $\mathrm{K}^{+}$. Their leached amounts increased with the increasing sodium chloride concentration of the permeant. The changes of $\mathrm{F}^{-}$and $\mathrm{HCO}_{3}{ }^{-}$were not obvious, but the leached amount was highest at a concentration of $0.1 \mathrm{~mol} \cdot \mathrm{L}^{-1}$. These phenomena may have been caused by a series of complicated soil and water interactions.

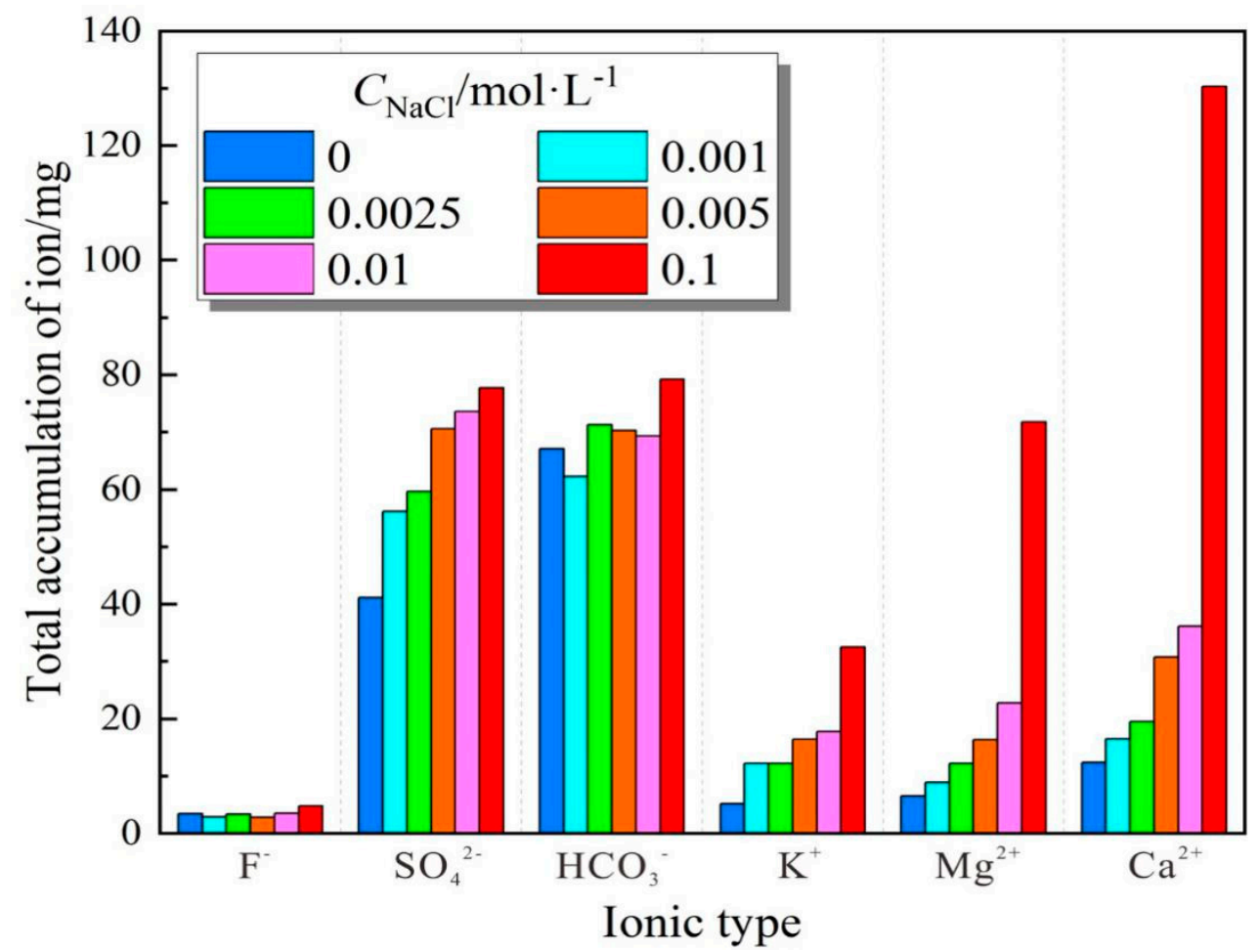

Figure 6. The influence of $\mathrm{NaCl}$ solution concentrations on the total cumulative mass of ions in the leachate.

\subsection{Characteristics of Soil Chemical Compositions}

To reflect the change of soil chemical composition and its response to the seepage of different sodium chloride solutions, the chemical compositions of the samples were measured after permeation, and the test results are shown in Figure 7. Combined with Tables 2 and 3, it can be seen that with the increasing $\mathrm{NaCl}$ concentration in the permeate, the contents of $\mathrm{MgO}$ and $\mathrm{CaO}$ in the loess decreased significantly after infiltration. The contents of $\mathrm{SiO}_{2}$ and $\mathrm{Al}_{2} \mathrm{O}_{3}$ in the soil samples increased with the increasing $\mathrm{NaCl}$ concentration after permeation. The $\mathrm{Fe}_{2} \mathrm{O}_{3}$ content also slightly increased and was not affected by the concentration of $\mathrm{NaCl}$ in the permeate. Moreover, the $\mathrm{K}_{2} \mathrm{O}$ content in the soil samples 
slightly increased after the infiltration of the $\mathrm{NaCl}$ solution with different concentrations (except for $\left.0.1 \mathrm{~mol} \cdot \mathrm{L}^{-1}\right)$. In regard to $\mathrm{Na}_{2} \mathrm{O}$, its content decreased after the $0,0.001$, and $0.0025 \mathrm{~mol} \cdot \mathrm{L}^{-1} \mathrm{NaCl}$ solution permeations, but it increased after the permeation of the other three concentrations of the $\mathrm{NaCl}$ solution. This may have been caused by the adsorption of a large number of $\mathrm{Na}^{+}$ions on the surface of clay minerals when the sodium chloride concentration exceeded $0.005 \mathrm{~mol} \cdot \mathrm{L}^{-1}$.

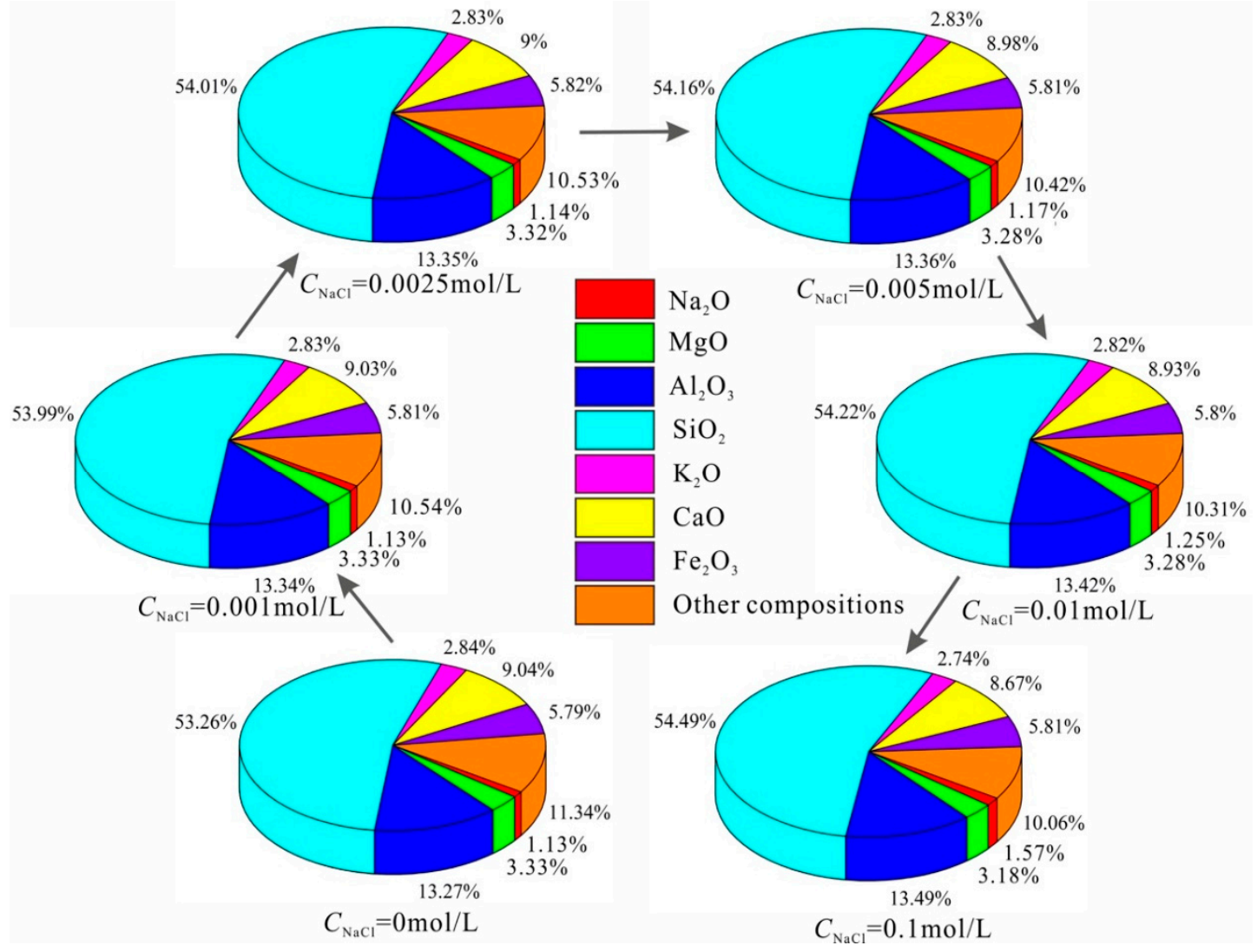

Figure 7. Chemical compositions of the loess samples after permeation.

\section{Discussion}

\subsection{Response of Permeability to Water-Soil Chemical Interaction}

Water-soil chemical interactions change the hydro-mechanical behavior of soil by transferring components between water and soil, mainly via dissolution and precipitation, exchange and adsorption, and redox reactions [20-22,38,39]. In particular, the influence of these actions on soil permeability are significant $[14,15,40,41]$.

\subsubsection{Dissolution and Precipitation}

Dissolution refers to the process of material transferal from minerals and salts to water, which can weaken the cementation strength of soil and thus improve the permeability of soil [20]. Precipitation refers to the reaction between an aqueous solution and the minerals in the soil, which form components that are difficult to dissolve in water. These components are consolidated to the pores or soil, resulting in a reduction of soil permeability [40].

In the previous section, the amounts of $\mathrm{Ca}^{2+}$ and $\mathrm{Mg}^{2+}$ in the osmotic solution increased with the increasing concentration of the $\mathrm{NaCl}$ solution, and the contents of $\mathrm{CaO}$ and $\mathrm{MgO}$ in the soil samples decreased after penetration. As indicated in Tables 2 and 3, CaO should mainly occur in carbonate minerals such as calcite and dolomite, while $\mathrm{MgO}$ basically occurs in chlorite and dolomite. The conversion of chlorite to montmorillonite can retain $\mathrm{MgO}$ content in soil, but the dissolution 
of dolomite often leads to a decrease of the $\mathrm{MgO}$ content [24]. Hence, the decreasing $\mathrm{MgO}$ content indicated that dolomite dissolution was dominant. According to Equations (5) and (6), the dissolutions of calcite and dolomite provided more $\mathrm{Ca}^{2+}$ than $\mathrm{Mg}^{2+}$, which could explain why the decrease of $\mathrm{CaO}$ was more significant than that of $\mathrm{MgO}$ and why the increase of $\mathrm{Ca}^{2+}$ in the osmotic solution was more obvious than that of $\mathrm{Mg}^{2+}$. Furthermore, increasing the concentration of $\mathrm{NaCl}$ can promote the dissolution of carbonate minerals. Other scholars also have obtained similar findings, proving that the salt effect is helpful for the dissolution of carbonate minerals [42-44]. Consequently, the ionic activity of a solution decreases with the increasing concentration of sodium chloride, which leads to an increase of mineral solubility under certain temperatures and pressures [42,44]. Moreover, previous studies have shown that there is a large amount of $\mathrm{Ca}^{2+}$ loss in soil, and this causes the soil skeleton to loosen and the degree of connection to weaken [45-47]. Similarly, as an important part of the loess skeleton, carbonate minerals can inevitably increase porosity with increasing loss degrees. Therefore, the saturated permeability of loess shows an enhanced behavior with increasing $\mathrm{NaCl}$ concentrations in a solution.

Calcite dissolution:

$$
\mathrm{CaCO}_{3}+\mathrm{H}_{2} \mathrm{O}+\mathrm{CO}_{2} \rightarrow 2 \mathrm{HCO}_{3}^{-}+\mathrm{Ca}^{2+}
$$

Dolomite dissolution:

$$
\mathrm{MgCa}\left(\mathrm{CO}_{3}\right)_{2}+2 \mathrm{H}_{2} \mathrm{O}+2 \mathrm{CO}_{2} \rightarrow 4 \mathrm{HCO}_{3}^{-}+\mathrm{Ca}^{2+}+\mathrm{Mg}^{2+}
$$

As indicated by Table 3 and Figure 7, the $\mathrm{K}_{2} \mathrm{O}$ increment was $0.07-0.05 \%$ after penetration, and it decreased with increasing $\mathrm{NaCl}$ solution concentrations (except for $0.1 \mathrm{~mol} \cdot \mathrm{L}^{-1}$ ). The $\mathrm{K}_{2} \mathrm{O}$ content was mainly related to illite [24], and the amount of $\mathrm{K}^{+}$in the solution increased with the increasing $\mathrm{NaCl}$ concentration, especially at $0.1 \mathrm{~mol} \cdot \mathrm{L}^{-1}$ (Figure 6). This not only indicates illite dissolution but also its supply sources in the process of seepage. Orthoclase (potash aluminosilicate) is the most stable feldspar mineral under the action of hydrochemistry [48-50]. Sodium chloride can inhibit the dissolution of feldspar [51,52], resulting in the reduced ability of orthoclase to transform into illite. Additionally, in this experiment, the soil permeability was enhanced by the dissolution of the carbonate minerals, and then the dissolution of illite is also enhanced by the action of water flow. Therefore, the discharge of $\mathrm{K}^{+}$increased significantly, and the content of $\mathrm{K}_{2} \mathrm{O}$ decreased significantly at a sodium chloride concentration of $0.1 \mathrm{~mol} \cdot \mathrm{L}^{-1}$.

The content of $\mathrm{SiO}_{2}$ is mainly determined by quartz minerals, and $\mathrm{Al}_{2} \mathrm{O}_{3}$ mainly occurs in clay minerals. Their contents increased at different degrees after permeation. The original rock components in the soil were eroded by the water flow in the process of seepage, and the formed clastic soil particles adhered to the pores and settled. This resulted in increases of quartz and clay minerals at varying degrees [24]. In addition, the formation of clay minerals with high hydrophilicity promotes the chemical action of soil and water [45]. Thus, the soil structure loosened, thus enhancing permeability.

\subsubsection{Redox Action}

In a water and soil system, the electron exchange between the gas phase, the solid phase, and the dissolved components leads to an oxidation-reduction reaction. The reaction sequence can be basically divided into four stages with time [20,53]. Figure 8 shows that $\mathrm{Fe}^{3+}$ can only be reduced to $\mathrm{Fe}^{2+}$ without $\mathrm{O}_{2}$ and $\mathrm{NO}_{3}{ }^{-}$in a water-soil system. In this experiment, the dissolved oxygen that was carried by the permeate continuously entered the soil, and the dissolution of the soluble salts in the soil produced $\mathrm{NO}_{3}{ }^{-}$, which could have ensured the oxidation of $\mathrm{Fe}^{2+}$ to $\mathrm{Fe}^{3+}$. Therefore, the content of $\mathrm{Fe}_{2} \mathrm{O}_{3}$ slightly increased after infiltration (Figure 7). Peng et al. [24] also showed that reduced iron is easily oxidized to insoluble $\mathrm{Fe}_{2} \mathrm{O}_{3}$ in the process of soil-water interactions. However, since the content of hematite was $0.2 \%$, even if $\mathrm{Fe}_{2} \mathrm{O}_{3}$ precipitated in the pores, it exerted little effect on the permeability of the samples. 


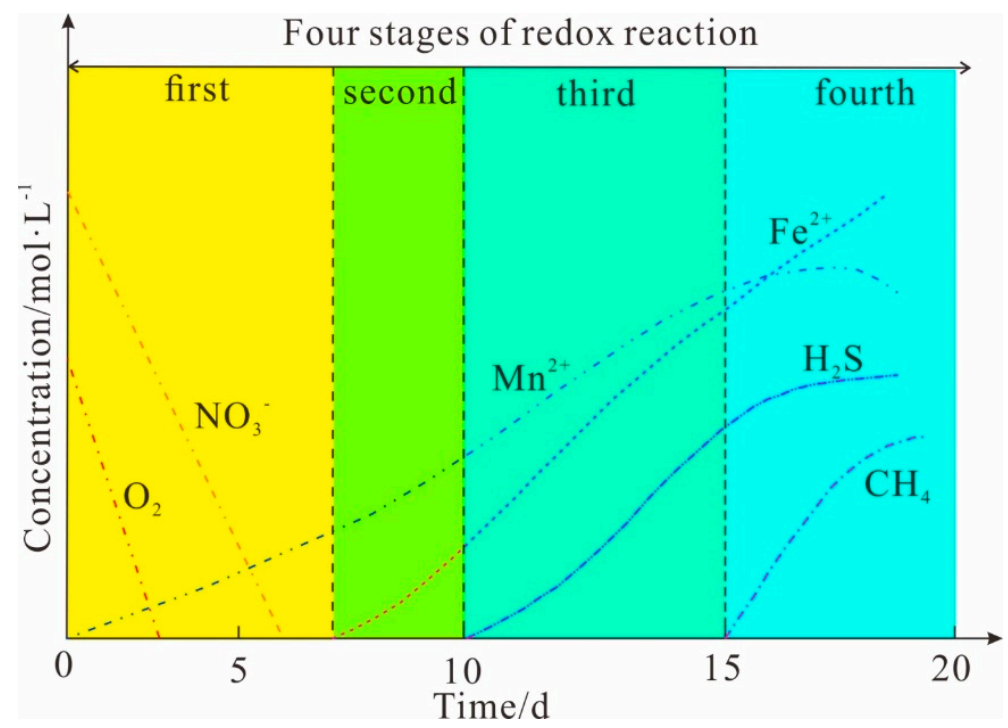

Figure 8. The theoretical sequence of the redox action after water infiltrating to soil [compiled from: 20].

\subsubsection{Exchange and Adsorption}

Exchange and adsorption, which are reversible, refer to the process of the conversion between the adsorbed ions on a particle's surface and the ions in a solution [54]. This action controls other physical-chemical properties of soil, such as hydraulic conductivity, by changing the thickness of the diffuse double layer (DDL) on the surface of soil particles $[14,19,39,40,55]$. A DDL structure diagram is shown in Figure 9.

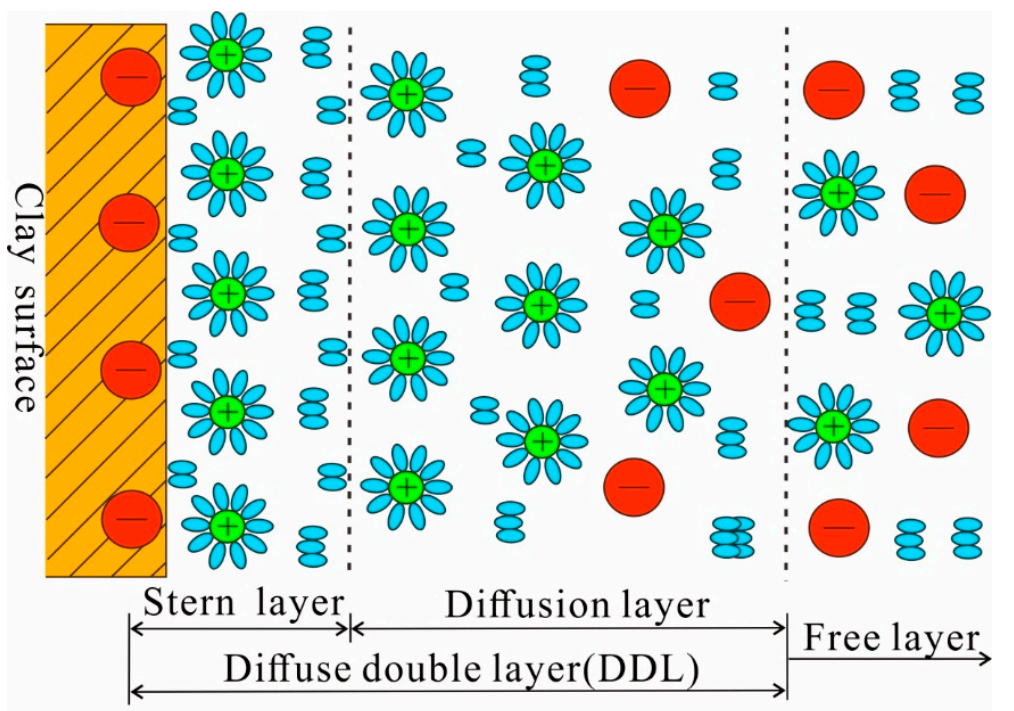

\section{Anion $\oplus$ Cation $\odot$ Water molecule}

Figure 9. The structure diagram of the diffuse double layer (compiled from [19]).

The saturated hydraulic conductivity of the remolded loess samples increased with the increasing concentration of the $\mathrm{NaCl}$ solution. Similar studies by most other researchers have suggested that the hydraulic conductivity of clay increases with the increasing concentration of inorganic salt solutions $[56,57]$. With increasing the concentration of a pore solution, the double electric layer is compressed, and the trellis pores that are formed between the particles increase the soil's porosity, thus resulting in an increase of soil permeability [13]. Furthermore, Chen et al. found that the thickness 
of the DDL that was obtained by quantitative calculation decreased with increasing $\mathrm{NaCl}$ concentration, while the permeability of the clay increased [19].

Compared with the dissolution precipitation and redox reaction, the ion exchange reaction is fastest [20]. In the present study, with the increasing concentration of sodium chloride, $\mathrm{Ca}^{2+}, \mathrm{Mg}^{2+}$, and $\mathrm{K}^{+}$were gradually replaced by $\mathrm{Na}^{+}$in the soil because of the reversibility of the cation exchange. This was also the reason for the increase of these ions in the exudate. This led to the dispersion of clay particles, thus enabling the full contact of the solution with the soil and promoting the dissolution of other mineral components (notably the salt effect of calcite and dolomite). Importantly, sodium ions diffused into the stern layer because of the increase of the $\mathrm{NaCl}$ concentration, thus compressing the diffuse double layer and increasing the free layer (Figure 9). Therefore, the saturated permeability of the remolded loess increased with the increasing $\mathrm{NaCl}$ concentration.

\subsection{Response of Permeability to the Soil Microstructure}

With the increasing concentration of a water solution in pores, the thickness of the DDL of clay particles decreases, which increases physical-chemical forces and forms aggregates of particles that are coarser than clay and larger pores between aggregates [28,32,58-60]. The increasing tendency of saturated permeability with increasing $\mathrm{NaCl}$ concentrations can also be explained by this microscopic mechanism.

Figure 10 presents SEM images of the microstructure evolution of the remolded loess after permeation by different concentrations of the sodium chloride solution. As the concentration of $\mathrm{NaCl}$ increased, the behavior of the clay aggregation became more obvious, and the roughness of the soil surface increased. This phenomenon was caused by the sodium ions diffusing into the clay surface, thus resulting in a decrease of the electrostatic repulsion and an increase of the Van der Waals' attractive force among the clay particles. Moreover, with developing permeation, several types of salts were leached, especially carbonate as calcium cement, which led to the loosening of the structure with a larger pore space. This was also the direct reason why the permeability increased with the concentration of the $\mathrm{NaCl}$ solution.

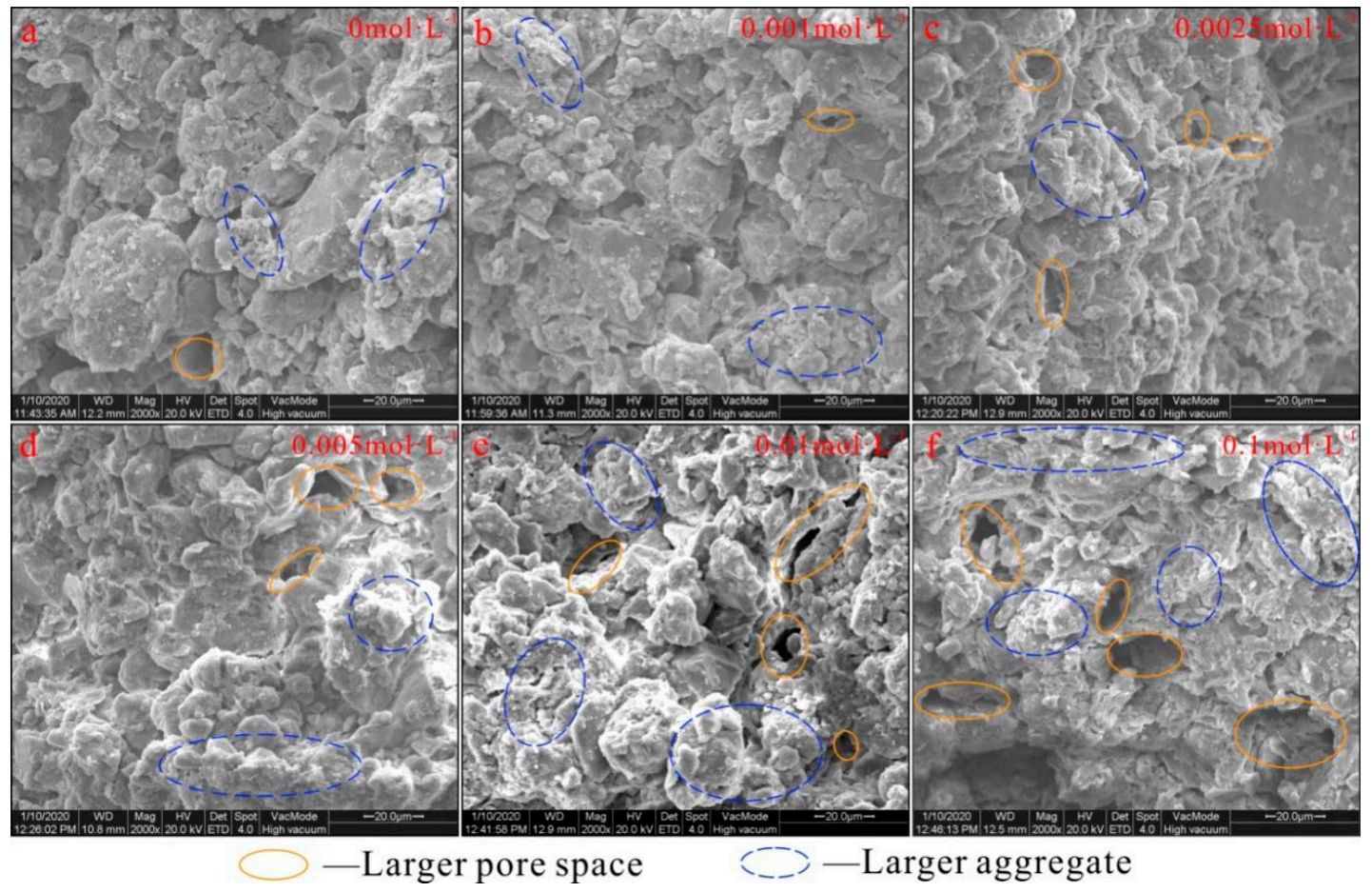

Figure 10. SEM images of the samples that were permeated by different $\mathrm{NaCl}$ concentrations. (a) $0 \mathrm{~mol} / \mathrm{L}$; (b) $0.001 \mathrm{~mol} / \mathrm{L}$; (c) $0.0025 \mathrm{~mol} / \mathrm{L}$; (d) $0.005 \mathrm{~mol} / \mathrm{L}$; (e) $0.01 \mathrm{~mol} / \mathrm{L}$; (f) $0.1 \mathrm{~mol} / \mathrm{L}$. 


\section{Conclusions}

This study designed a series of saturated permeability tests on remolded loess to explore the influence of different concentrations of an $\mathrm{NaCl}$ solution on saturated hydraulic conductivity. The following conclusions were obtained:

The $K_{\text {sat }}$ of the remolded loess samples increased with time during the entire process of permeation. The permeability was positively related to the total leaching ability of ions. The content of $\mathrm{MgO}$ and $\mathrm{CaO}$ in the loess decreased significantly with increasing $\mathrm{NaCl}$ concentrations after permeation, while the contents of $\mathrm{SiO}_{2}$ and $\mathrm{Al}_{2} \mathrm{O}_{3}$ increased. In addition, the increase of $\mathrm{Fe}_{2} \mathrm{O}_{3}$ after permeation was caused by the oxidation of the reduced iron.

With the increasing $\mathrm{NaCl}$ concentration, the salt effect promoted the dissolution of calcite and dolomite, thus causing the loss of calcium cement, which resulted in a loosening of the structure of the soil samples. Cation exchange also promoted $\mathrm{Ca}^{2+}, \mathrm{Mg}^{2+}$, and $\mathrm{K}^{+}$leaching, the dissolution of related minerals, and the dispersion of clay particles.

$\mathrm{Na}^{+}$was able to diffuse into the stern layer, thus compressing the diffuse double layer, which led to an increase of the free layer and the provision of more pore space for the flow. Furthermore, the aggregate of the clay particles increased, and larger pores among the aggregates were also formed because of the increasing force between the clay particles.

Author Contributions: Conceptualization, H.Q.; Methodology, P.X.; Software, P.X. and Q.Z.; Validation: H.Q.; Formal analysis, P.X.; Investigation, P.X.; Resources, P.X.; Data curation, W.Q. and Q.Z.; Writing-original draft preparation, P.X.; Writing—review and editing, H.Q.; Visualization, H.Q.; Supervision, H.Q.; Project administration, H.Q. and P.X.; Funding acquisition, P.X. All authors have read and agreed to the published version of the manuscript.

Funding: We are grateful for the support from the Scientific Innovation Practice Project of Postgraduates of Chang'an University (Grant No. 300103002026).

Conflicts of Interest: The authors declare no conflict of interest.

\section{References}

1. Li, P.; Xie, W.; Pak, R.Y.; Vanapalli, S.K. Microstructural evolution of loess soils from the Loess Plateau of China. Catena 2019, 173, 276-288. [CrossRef]

2. Peng, J.; Wang, S.; Wang, Q.; Zhuang, J.; Huang, W.; Zhu, X.; Leng, Y.; Ma, P. Distribution and genetic types of loess landslides in China. J. Asian Earth Sci. 2019, 170, 329-350. [CrossRef]

3. An, P. Experimental Study on Seepage Degradation of Reshape Saturated Loess under Seepage. Master's Thesis, Northwest A \& F University, Yangling, China, 2011. (In Chinese).

4. An, P.; Zhang, A.J.; Liu, H.T.; Wang, T. Degradation mechanism of long-term seepage and permeability analysis of remolded saturated loess. Rock Soil Mech. 2013, 34, 1965-1971. (In Chinese)

5. Liu, Z.; Dugan, B.; Masiello, C.A.; Barnes, R.T.; Gallagher, M.E.; Gonnermann, H. Impacts of biochar concentration and particle size on hydraulic conductivity and DOC leaching of biochar-sand mixtures. $J$. Hydrol. 2016, 533, 461-472. [CrossRef]

6. Chapuis, R.P. Predicting the saturated hydraulic conductivity of soils: A review. Bull. Eng. Geol. Environ. 2012, 71, 401-434. [CrossRef]

7. Gao, Y.; Qian, H.; Li, X.; Chen, J.; Jia, H. Effects of lime treatment on the hydraulic conductivity and microstructure of loess. Environ. Earth Sci. 2018, 77, 529. [CrossRef]

8. Mu'Azu, M.A. Influence of compactive effort on Bagasse ash with cement treated lateritic soil. Leonardo Electron. J. Pract. Technol. 2007, 10, 79-92.

9. Metelková, Z.; Boháč, J.; Přrikryl, R.; Sedlářová, I. Maturation of loess treated with variable lime admixture: Pore space textural evolution and related phase changes. Appl. Clay Sci. 2012, 61, 37-43. [CrossRef]

10. Cuisinier, O.; Auriol, J.C.; Le Borgne, T.; Deneele, D. Microstructure and hydraulic conductivity of a compacted lime-treated soil. Eng. Geol. 2011, 123, 187-193. [CrossRef]

11. Yan, G.S.; Zhang, H.Y.; Li, H.P.; Hu, X.Y. Research on permeability experiment of modified loess. Coal Ash 2013, 25, 1-5. (In Chinese) 
12. Cai, N.; Cao, L.W.; Shang, J.Q. Effect of chemical on the permeability of silt in the seepage process of inorginic solution. Sci. Technol. Eng. 2018, 18, 312-317. (In Chinese)

13. Zhang, J. Study on the influence of inorganic salt solution on the permeability of silty clay. Technol. Innov. Appl. 2017, 16, 75. (In Chinese)

14. Yılmaz, G.; Yetimoglu, T.; Arasan, S. Hydraulic conductivity of compacted clay liners permeated with inorganic salt solutions. Waste Manag. Res. 2008, 26, 464-473. [CrossRef] [PubMed]

15. Jo, H.Y.; Katsumi, T.; Benson, C.H.; Edil, T.B. Hydraulic conductivity and swelling of nonprehydrated GCLs permeated with single-species salt solutions. J. Geotech. Geoenviron. Eng. 2001, 127, 557-567. [CrossRef]

16. Xu, H.; Yang, X. Releasing of major elements from loess leached by rain. Soil Environ. Sci. 2002, 11, 38-41. (In Chinese)

17. Guo, Y.W.; Zhang, Y.L.; Dang, X.L.; Jia, T.C. Behaviors of $\mathrm{CaCO}_{3}$ in Loess collapse caused by irrigation. Acta Pedol. Since 2008, 45, 1034-1039. (In Chinese)

18. Kolstad, D.C.; Benson, C.H.; Edil, T.B. Hydraulic conductivity and swell of nonprehydrated geosynthetic clay liners permeated with multispecies inorganic solutions. J. Geotech. Geoenviron. Eng. 2004, 130, 1236-1249. [CrossRef]

19. Chen, J.; Fang, Y.; Gu, R.; Shu, H.; Ba, L.; Li, W. Study on pore size effect of low permeability clay seepage. Arab. J. Geosci. 2019, 12, 238. [CrossRef]

20. Wang, J.H.; Peng, Z.B.; Du, C.X. Chemical interaction of water-soil within slope. Chin. J. Geol. Hazard Control 2006, 2, 69-73. (In Chinese)

21. Nguyen, X.-P.; Cui, Y.-J.; Tang, A.M.; Deng, Y.; Li, X.-L.; Wouters, L. Effects of pore water chemical composition on the hydro-mechanical behavior of natural stiff clays. Eng. Geol. 2013, 166, 52-64. [CrossRef]

22. Godoy, V.A.; Zuquette, L.V.; Gómez-Hernández, J.J. Spatial variability of hydraulic conductivity and solute transport parameters and their spatial correlations to soil properties. Geoderma 2019, 339, 59-69. [CrossRef]

23. Zhang, X.G.; Ma, G.W.; Yi, N.; Chen, X.; Wu, H. Experimental analysis of chemical damage of water to soil structure. In Key Engineering Materials; Trans Tech Publications Ltd.: Bäch, Switzerland, 2007.

24. Zhu, W.; Xu, H.Q.; Wang, S.W.; Fan, X.H. Influence of $\mathrm{CaCl}_{2}$ solution on the permeability of different clay-based cutoff walls. Rock Soil Mech. 2016, 37, 1224-1230. (In Chinese)

25. Jing, D.; Pan, Y. Electroviscous effect and convective heat transfer of pressure-driven flow through microtubes with surface charge-dependent slip. Int. J. Heat Mass Transf. 2016, 101, 648-655. [CrossRef]

26. Gleason, M.H.; Daniel, D.E.; Eykholt, G.R. Calcium and sodium bentonite for hydraulic containment applications. J. Geotech. Geoenviron. Eng. 1997, 123, 438-445. [CrossRef]

27. Kaya, A.; Fang, H.-Y. The effects of organic fluids on physicochemical parameters of fine-grained soils. Can. Geotech. J. 2000, 37, 943-950. [CrossRef]

28. Jia, Y.J.; Zhuang, J.Q.; Wang, Y.; Zhao, Y.; Niu, P.Y.; Jia, K.C. Experimental study for effect of sodium sulfate's concentration on shear strength of loess. J. Eng. Geol. 2019, 27, 1041-1047. (In Chinese)

29. Ministry of Water Resources of the Peoples' Republic of China. Standard for Soil Test Method (GB/T 50123-1999); China Planning Press: Beijing, China, 1999. (In Chinese)

30. Xu, P.P.; Feng, W.W.; Qian, H.; Liu, F.X. Discussion on comparison and accuracy of reusable soil compaction test. J. Eng. Geol. 2017, 25, 129-133.

31. Sun, J.Z. Loess Science (First Part); Hong Kong Archaeological Society Press: Hong Kong, China, 2005. (In Chinese)

32. Wen, B.-P.; He, L. Influence of lixiviation by irrigation water on residual shear strength of weathered red mudstone in Northwest China: Implication for its role in landslides' reactivation. Eng. Geol. 2012, 151, 56-63. [CrossRef]

33. Wang, J.J.; Qiu, Z.F. Anisotropic hydraulic conductivity and critical hydraulic gradient of a crushed sandstone-mudstone particle mixture. Mar. Georesour. Geotechnol. 2017, 35, 89-97. [CrossRef]

34. Fener, M.; Yesiller, N. Vertical pore structure profile of a compacted clayey soil. Eng. Geol. 2013, 166, $204-215$. [CrossRef]

35. Chen, W.; Ma, Y.; Yu, H.; Li, F.; Li, X.; Sillen, X. Effects of temperature and thermally-induced microstructure change on hydraulic conductivity of Boom Clay. J. Rock Mech. Geotech. Eng. 2017, 9, 383-395. [CrossRef] 
36. Ye, W.M.; Wan, M.; Chen, B.; Chen, Y.G.; Cui, Y.J.; Wang, J. Temperature effects on the swelling pressure and saturated hydraulic conductivity of the compacted GMZ01 bentonite. Environ. Earth Sci. 2013, 68, 281-288. [CrossRef]

37. Zhang, M.; Zhu, X.; Yu, G.; Yan, J.; Wang, X.; Chen, M.; Wang, W. Permeability of muddy clay and settlement simulation. Ocean Eng. 2015, 104, 521-529. [CrossRef]

38. Yang, X.J.; Wang, Y.; Fan, H.H.; Xu, N.R. Effects of pore solution's pH value on engineering properties of remolded loess. J. Yangtze River Sci. Res. Inst. 2018, 35, 92-97. (In Chinese)

39. Mitchell, J.K.; Soga, K. Fundamentals of Soil Behavior; John Wiley \& Sons: Hoboken, NJ, USA, 2005.

40. Wang, T.; Zhang, A.J.; Liu, H.T.; An, P. Permeability properties of reshaped loess in osmotic solution of different acidities. J. Yangtze River Sci. Res. Inst. 2013, 30, 35-40. (In Chinese)

41. Liu, H.-m.; Zhou, D.; Wu, H.; Jiao, W.-C.; Wang, Y.-T. Experimental study on water-soil interaction influence for environmental change of marine soft soil. In Civil, Architecture and Environmental Engineering; CRC Press: Taipei, China, 2017; pp. 1239-1246.

42. Chen, Y.; Wang, Y.; Liu, Q.; Zhuo, Q.G.; Zhang, X.J.; Chen, X.L. Effect of salts and common ions on solubility of calcite and its geological implications. J. China Univ. Pet. 2016, 40, 33-39. (In Chinese)

43. Newton, R.C.; Manning, C.E. Experimental determination of calcite solubility in $\mathrm{H} 2 \mathrm{O}-\mathrm{NaCl}$ solutions at deep crust/upper mantle pressures and temperatures: Implications for metasomatic processes in shear zones. Am. Mineral. 2002, 87, 1401-1409. [CrossRef]

44. Yan, Z.W.; Zhang, Z.W. The effect of chloride on the solubility of calcite and dolomite. Hydrogeol. Eng. Geol. 2009, 36, 113-118. (In Chinese)

45. Liu, Y.; Liang, H.C.; Tang, Z.H.; Cai, H.S.; Liu, J.W. Inverse modeling of geochemical behavior of Ca2+ in landslide water-soil interaction system near the Three Gorges Reservoir. Hydrogeol. Eng. Geol. 2012, 39, 106-110. (In Chinese)

46. Gratchev, I.B.; Towhata, I. Effects of acidic contamination on the geotechnical properties of marine soils in Japan. In Proceedings of the Nineteenth International Offshore and Polar Engineering Conference, Osaka, Japan, 21-26 July 2009.

47. Gratchev, I.; Towhata, I. Compressibility of natural soils subjected to long-term acidic contamination. Environ. Earth Sci. 2011, 64, 193-200. [CrossRef]

48. Holdren, G.R., Jr.; Speyer, P.M. Reaction rate-surface area relationships during the early stages of weathering. II. Data on eight additional feldspars. Geochim. Cosmochim. Acta 1987, 51, 2311-2318. [CrossRef]

49. Huang, W.L.; Longo, J.M. The effect of organics on feldspar dissolution and the development of secondary porosity. Chem. Geol. 1992, 98, 271-292. [CrossRef]

50. Zhang, Y.W.; Zeng, J.H.; Zhang, S.W.; Wang, Y.S.; Zhang, S.P. An Overview of Feldspar Dissolution Experiments. Geol. Sci. Technol. Inf. 2009, 28, 31-37. (In Chinese)

51. Blake, R.; Walter, L. Effects of organic acids on the dissolution of orthoclase at $80 \mathrm{C}$ and pH 6. Chem. Geol. 1996, 132, 91-102. [CrossRef]

52. Blake, R.E.; Walter, L.M. Kinetics of feldspar and quartz dissolution at $70-80{ }^{\circ} \mathrm{C}$ and near-neutral pH: Effects of organic acids and NaCl. Geochim. Cosmochim. Acta 1999, 63, 2043-2059. [CrossRef]

53. Ross, S. Soil Processes: A Systematic Approach; Routledge: Abingdon, UK, 1989.

54. Chen, G.X.; Fan, L.B.; Chen, S. Soil Science and Soil Mechanics, 2nd ed.; China Water \& Power Press: Beijing, China, 2006. (In Chinese)

55. Fukue, M.; Minato, T.; Horibe, H.; Taya, N. The micro-structures of clay given by resistivity measurements. Eng. Geol. 1999, 54, 43-53. [CrossRef]

56. Lee, J.-M.; Shackelford, C.D. Impact of bentonite quality on hydraulic conductivity of geosynthetic clay liners. J. Geotech. Geoenviron. Eng. 2005, 131, 64-77. [CrossRef]

57. Lee, J.-M.; Shackelford, C.D.; Benson, C.H.; Jo, H.-Y.; Edil, T.B. Correlating index properties and hydraulic conductivity of geosynthetic clay liners. J. Geotech. Geoenviron. Eng. 2005, 131, 1319-1329. [CrossRef]

58. Fan, X.; Xu, Q.; Scaringi, G.; Li, S.; Peng, D. A chemo-mechanical insight into the failure mechanism of frequently occurred landslides in the Loess Plateau, Gansu Province, China. Eng. Geol. 2017, 228, 337-345. [CrossRef] 
59. Tiwari, B.; Tuladhar, G.R.; Marui, H. Variation in residual shear strength of the soil with the salinity of pore fluid. J. Geotech. Geoenviron. Eng. 2005, 131, 1445-1456. [CrossRef]

60. Zhang, F.; Wang, G.; Kamai, T.; Chen, W.; Zhang, D.; Yang, J. Undrained shear behavior of loess saturated with different concentrations of sodium chloride solution. Eng. Geol. 2013, 155, 69-79. [CrossRef]

(C) 2020 by the authors. Licensee MDPI, Basel, Switzerland. This article is an open access article distributed under the terms and conditions of the Creative Commons Attribution (CC BY) license (http://creativecommons.org/licenses/by/4.0/). 